\title{
Gelir ve Mutluluk: Gelir Karşılaştırmasının Etkisi
}

Onur KÖKSAL, Department of Business Administration, Faculty of Economics and Administrative Sciences, Nigde University, Turkey; e-mail: okoksal@nigde.edu.tr

Faruk SSAHIN, Department of International Trade and Logistics, Fethiye Faculty of Management, Mugla Sitki Kocman University, Turkey; e-mail: faruksahin@mu.edu.tr

\section{Income and Happiness: The Effect of Income Comparison}

\begin{abstract}
The purpose of this paper was to examine the effect of income comparison in the relationship between income and happiness on Turkish sample. The research data was obtained from Life Satisfaction Survey carried out by Turkey Statistical Institute in 2012. The research sample consisted of 7956 individuals. As part of the purpose of this paper, hierarchical regression analyses were conducted to examine the main and interaction effects of income and income comparison on individual happiness. According to the analysis results, as individuals perceived their own welfare higher than others, the effect of income on happiness decreased. These results are significant in terms of individuals could not be happier even in high welfare state perception.
\end{abstract}

Keywords : Income, Happiness, Income Comparison.

JEL Classification Codes : D31, M10.

\section{$\ddot{\mathbf{O z}}$}

$\mathrm{Bu}$ çalışmanın amacı, gelir ve mutluluk arasındaki ilişkide gelir karşılaştırmasının etkisini Türkiye örneklemi üzerinde incelemektir. Araştırmanın verisi, Türkiye İstatistik Kurumu tarafından 2012 yılında gerçekleştirilen Yaşam Memnuniyeti Araştırması'ndan elde edilmiştir. Bu araştırmaya katılan 7956 kişi araştırmanın örneklemini oluşturmaktadır. Çalışmanın amacı kapsamında, bireylerin mutlulukları üzerinde gelirin ve gelir karşılaştırmasının tek tek etkisi ve birlikte etkisinin (interaction) belirlenmesi amacıyla hiyerarşik regresyon analizi kullanılmıştır. Analiz sonuçlarına göre, bireyler başkalarına göre kendi refah düzeyi algılamasında yükseldikçe, gelirin mutluluk üzerindeki etkisi zayıflamaktadır. Bu bulgular, yüksek refah düzeyi algılaması durumlarında bile bireylerin mutlu olamadıklarını ortaya koyması açısından önem arz etmektedir.

Anahtar Sözcükler $\quad$ : Gelir, Mutluluk, Gelir Karşılaştırması. 


\section{Giriş}

Toplumların ortalama mutluluk düzeyleri ile ortalama kişi başına düşen gelir düzeyleri arasında anlamlı ve güçlü bir ilişki olduğu belirtilmektedir (Diener \& Seligman, 2004; Erdogan vd., 2012). Bu ilişki, sosyal refah düzeyi yüksek toplumların -zengin toplum da denilebilir- düşük toplumlara göre daha mutlu olduklarını göstermektedir (Veenhoven, 1991; Diener vd., 1995; Arthaud-Day \& Near, 2005; Dumludag, 2013). Bu tarz ülkelerde yaşayan insanların hayat standartları yüksektir (Van Praag \& Baarsma, 2005). Böyle ülkelerde insanlar yüksek gelirleri sayesinde pahalı arabalar ve büyük evler alabilirler, boş vakitlerini lüks eğlencelerle geçirebilirler, son teknoloji ürünleri rahatlıkla satın alabilirler ve diledikleri ülkelere seyahat edebilirler (Cummins, 2000; Ferrer-i-Carbonell, 2005). Kısacası bu durum, bireylerin temel ihtiyaçlarını rahatlıkla karşılamalarını ve kişisel gelişimleri için ihtiyaç duydukları kaynaklara kolaylıkla ulaşabilmelerini sağlamaktadır. Ancak, gelişmiş ülkeler ve gelişmekte olan ülkeler arasındaki gelir aralığı, bu ülkelerde yaşayan bireylerin daha mutlu ya da daha az mutlu şeklinde sınıflandırılmasının nedeni değildir (Erdogan vd., 2012). Nitekim Frey ve Stutzer (2002) tarafından yapılan çalışmada kişi başına düşen gelir miktarının 10.000 \$'1 aşması durumunda mutluluk düzeyinde çok küçük artışlar olduğu ifade edilmektedir. Diğer taraftan, ilgili alan yazında yapılan bazı çalışmalarda zengin olmayan toplumlarda gelir ve mutluluk arasındaki ilişkinin daha güçlü olduğu bulunmuştur (Veenhoven, 1991; Diener \& Diener, 1995; Diener \& Oishi, 2000). Bu anlamda, zengin toplumlarda meydana gelen her gelir artışının beraberinde mutluluk getirmediği sonucuna ulaşılabilir (Firebaugh \& Schroeder, 2009). Her ne kadar bir ülkedeki zengin bireyler fakirlere kıyasla daha mutlu olsalar da, belirli bir seviyenin üzerindeki gelir artışı, bireylerin mutluluk düzeylerinde yükselişe öncülük etmeyebilir (Ferrer-i-Carbonell, 2005). Diğer bir ifadeyle, ülke ekonomisinin büyümesiyle birlikte meydana gelen sosyal refah düzeyindeki yükselme, herkesin mutluluğunda aynı düzeyde artışı tetiklememektedir (Duncan, 1975; Caporale vd., 2009). Çünkü bireysel gelir artışının mutluluk üzerindeki pozitif etkisi, genel gelir artışının neden olduğu daha yüksek yaşam standartlarının negatif etkisi tarafından dengelenmektedir (Easterlin, 1995). Böylece, elde edilen gelirden sağlanan doyumun bireyden bireye farklılaşabileceğini, diğer bir ifadeyle de göreceli bir doyum olduğunu söylemek mümkündür (Senik, 2005). Nitekim Rojas (2007) tarafından yapılan çalışmada gelirin mutluluk üzerindeki etki derecesinin bireyden bireye farklılık gösterdiği sonucuna ulaşılmıştır. Böylece, bireylerin mutlu yaşam hakkındaki düşüncelerinin farklı olduğu söylenebilir.

Paranın insanların mutluluk düzeyleri üzerinde önemli bir etken olduğu varsayımından hareketle (Diener \& Biswas-Diener, 2002), yüksek gelir sahibi bireylerin daha mutlu oldukları söylenebilir (Easterlin, 2001; Diener \& Seligman, 2004). Çünkü gelir, bireylerin ihtiyaçlarını karşılamalarında faydalandıkları en önemli araçtır (Boyce vd., 2010). İlgili alan yazında gelir ve mutluluk arasındaki ilişkiyi açıklamada üç farklı teoriden sıklıkla faydalanılmaktadır. Bunlar; beklenti teorisi (expectation theory), adaptasyon teorisi 
(adaptation theory) ve son olarak sosyal kiyaslama teorisidir (social comparison theory) (Diener vd., 1993; Arthaud-Day \& Near, 2005; Dumludag, 2013; Caner, 2014).

Beklenti teorisine göre bireyler gelire dayalı beklentilerini karşıladıklarında mutlu olmaktadırlar (Clark vd., 2008). Gelire dayalı beklenti, bir kimsenin şu anda sahip oldukları ile geçmişte sahip oldukları veya gelecekte sahip olmayı bekledikleri arasındaki aralığı ifade etmektedir. Bu anlamda, amaçlarına ulaşan bireylerin (aralığın kapandığ mutlu, ulaşamayan bireylerin (aralığın açıldığı) ise mutlu olmadıkları söylenebilir (ArthaudDay \& Near, 2005). Bu teoriye göre, bugün gelirde meydana gelen bir artış bireyin geleceğe dair beklentisinde eşit düzeyde bir artışa öncülük ediyorsa, aralığın büyüklüğü sabit kalmakta ve böylece yaşam doyumunda herhangi bir değişiklik meydana gelmemektedir (Hagerty \& Veenhoven, 2003; Rojas, 2007; Dumludag, 2013). Ayrıca, bireylerin gelir beklentileri, içerisinde yaşadıkları toplumun ortalama gelir düzeyi ve çevresindeki insanların gelir miktarı ile birlikte artmaktadır. Ancak, yüksek gelir beklentisi bireylerin mutluluğunu düşürmektedir (Stutzer, 2004). Bu anlamda, çevresindeki insanların durumlarında ortaya çıkan bir gelişme, kıyaslama yapan bireyin mutluluğunu olumsuz yönde etkilemektedir (McBride, 2010). Bireyler sürekli olarak daha fazlasını arzu ettiklerinden dolayı, mükemmel koşullar altında bile mutsuz olabilirler. Diğer taraftan, tatminkâr bireyler yoksulluk içerisinde bile mutlu olabilirler. Böylece, sürekli mutlu olmak pek fazla ihtimal dâhilinde olan bir durum değildir. Çünkü her yeni gelişim yeni bir beklentiyi tetiklemektedir (Veenhoven, 1991). Bireyler bugün geçmişten, gelecekte ise bugünden daha mutlu olacaklarını düşünmektedirler. Bireyleri böyle bir düşünceye sevk eden temel unsur gelirlerinin artacağına dair inançlarıdır. Ancak, gelirin artmasıyla beraber beklentilerin de yükselmesi sonucunda gerçekleşen mutluluk ile planlanan mutluluk arasında önemli bir farklılık ortaya çıkmaktadır (Easterlin, 2001).

Bireylerin gelire yönelik beklentilerinin şekillenmesinde elde ettikleri gelirle orantılı olarak kazandıkları tüketim alışkanlıklarının önemli bir payı vardır. Bireyler bu tüketim ya da gelir düzeyine adapte olmaktadırlar (Stutzer, 2004; Headey vd., 2008). Her ilave mal/hizmet tüketimi ya da gelir artışı kısa süreli ekstra bir mutluluk getirirken, zaman içerisinde cazibesini kaybetmekte ve böylece mutluluk orijinal düzeyine geri dönmektedir (Hagerty \& Veenhoven, 2003; Firebaugh \& Schroeder, 2009; Dumludag, 2013). Bu anlamda, gelirdeki değişim mutluluk üzerinde yalnızca geçici bir etkiye sahiptir. Çünkü bireyler mevcut ekonomik koşullarına adapte olmaktadırlar (Headey vd., 2008). Bu ifadelere karşılık gelen yaklaşım adaptasyon teorisi olarak adlandırılmaktadır. Adaptasyon teorisine göre bireysel ya da ulusal gelir düzeyinde meydana gelen değişim mutluluğun güçlü bir belirleyicisidir (Arthaud-Day \& Near, 2005). Bu doğrultuda teori, bireylerin pozitif ya da negatif olaylara uyum sağlama yeteneklerini ifade etmektedir. Uyum sağlama yetenekleri yüksek olan bireyler, gelir düzeyindeki değişikliklere kolaylıkla adapte olabilirler. Bunun gibi bireylerin mutluluk düzeyleri gelire göre değişiklik göstermemektedir (Rojas, 2007). 
Sosyal kıyaslama teorisine göre bireyler kendilerini, gelir, tüketim, statü ya da mutluluk gibi kriterler itibariyle bir referans grubuyla karşılaştırmaktadırlar (Veenhoven, 1991; Stutzer, 2004). Referans grup bir toplumdaki bütün bireyleri kapsadığı gibi aynı eğitim düzeyine sahip diğer insanlar ya da komşular gibi alt grupları da ihtiva etmektedir (Ferrer-i-Carbonell, 2005). Bunun yanında, referans grup içerisine arkadaşlar, akrabalar, akranlar (beş yaş küçük ya da büyük bireyler) ve çalışma arkadaşları da dahil edilmektedir (Firebaugh \& Schroeder, 2009; Caporale vd., 2009). Bireyler kıyaslamada genellikle yukarı doğru bakmaktadırlar (Veenhoven, 1991). Böylece, beklentiler bireylerin hali hazırda ulaştıkları düzeyin üzerini hedeflemektedir. Bireylerin bu karşılaştırmadan doyum sağlamaları durumunda (bireyin elde ettiği gelirin referans grup ortalamasından nispeten fazla ya da eşit olması durumu) elde ettikleri gelir mutluluklarının önemli bir belirleyicisi olabilmektedir (McBride, 2001; Arthaud-Day \& Near, 2005). Ancak, bireylerin elde ettikleri gelir referans grup düzeyinin altında kalırsa mutlulukları azalmaktadır (Boyce vd., 2010). $\mathrm{Bu}$ anlamda, referans grubun ortalama gelirinin bireylerin mutlulukları üzerinde negatif yönlü bir etkisinin olduğunu söylemek mümkündür. Kıyaslama etkisi, bireyin yalnızca kendi gelirini diğer insanların gelirleriyle karşılaştırmasını değil, aynı zamanda bireyin bugünkü geliri ile geçmişteki gelir düzeyi arasında yaptığı kıyaslamayı ifade etmektedir (Clark vd., 2008). İç kıyaslama (bireyin geçmişteki yaşam standartlarıyla yaptığı kıyaslama) dış kıyaslamaya (bireyin ekonomik basamak içerisinde kendisini sıralaması) göre daha güçlü bir araç olarak dikkat çekmektedir (Caner, 2014). Bunun yanında bireyler, mevcut durumlarını gelecekte tecrübe etmeyi bekledikleri durumları ile de kıyaslamaktadırlar (Hagerty \& Veenhoven, 2003; Stutzer, 2004). Bu anlamda, referans grupla yapılan kıyaslamanın mutluluk üzerindeki etkisine benzer şekilde, bireylerin finansal durumlarında yaşanan değişimlerin de (geçen yıla ya da bir sonraki yıla göre) yaşam doyumlarını etkilediğini ifade etmek mümkündür (Easterlin, 1995; Ferrer-i-Carbonell, 2005; Dolan vd., 2008). Bireylerin kendi hayatlarında gözlemledikleri her yeni gelişim doğrultusunda mutlulukları artarken, her bir kötüye gidiş mutlulukta bir miktar azalmaya neden olmaktadır (Veenhoven, 1991).

Bütün bu açıklamalardan hareketle, hahehalkı gelirinin mutluluk üzerinde önemli bir etkiye sahip olduğunu söylemek mümkündür. Bu etki üzerinde gerek iç gerekse diş kıyaslamanın rolü ise yadsınamamaktadır. Hem geçmişteki gelir kıyaslamasından hem de toplumdaki ortalama gelirden etkilenen yüksek gelir beklentileri çoğunlukla bireylerin mutlu olmalarının önüne geçmektedir. Öyle ki, Clark ve Oswald (1996) tarafından yapılan çalışmada mutluluk ve kıyaslamalı ücret oranları arasında negatif yönlü bir ilişki bulunmuştur. Her ne kadar bireysel doyumun artan gelirle birlikte yükseleceği fikri kabul görse de, insanların finansal doyumları üzerinde bireysel olarak sahip olduklarından ziyade, diğer insanlarla yaptıkları kıyaslama sonucunda neye sahip olmak istediklerine dair kanaatleri daha etkilidir (Duncan, 1975; Boyce vd., 2010). Nitekim Ball ve Chernova (2008) tarafından yapılan çalışmada diğer insanlarla yapılan kıyaslama sonucunda ortaya çıkan gelir düzeyindeki sayısal değişimin, bireysel gelirdeki değişime göre mutluluk üzerinde daha 
büyük bir etkiye sahip olduğu sonucuna ulaşılmıştır. Ayrıca, Caporale vd. (2009) tarafından 19 Avrupa ülkesinde yapılan kesitsel çalışmada gelir ve mutluluk arasında pozitif yönlü bir ilişki bulunmuş, ancak bu ilişki şiddetinin referans grup algılaması tarafından azaltıldığı ortaya çıkmıştır. İlgili alan yazında gerçekleştirilen birçok çalışmada da benzer sonuçlara rastlamak mümkündür (Near vd., 1978; Ferrer-i-Carbonell, 2005; Headey vd., 2008; Firebaugh \& Schroeder, 2009; McBride, 2010; Oishi vd., 2011; Oshio vd., 2011; Dumludag, 2013; Caner, 2014). Diğer taraftan, Diener vd. (2013) tarafından 135 farklı ulustan 806,526 kişi üzerinde yapılan çalışmada bir ülkede diğer insanlarla yapılan gelir kıyaslamasının bireysel yaşam değerlendirmeleri için anahtar bir belirleyici olmadığı, hatta bireysel gelirin mutluluk üzerinde daha güçlü bir etkiye sahip olduğu sonucuna ulaşılmıştır. İlgili alan yazında gelir kıyaslamasının mutluluğun güçlü bir belirleyicisi olduğu sonucuna ulaşan pek çok çalışmaya rastlansa da, az da olsa bu bulgunun tam tersi sonuca ulaşan çalışmalara da rastlamak mümkündür.

$\mathrm{Bu}$ ifadeler doğrultusunda, bu çalışmanın amacı; gelir ile mutluluk arasındaki ilişkide bireylerin gelir durumlarını karşılaştırmalarının etkisini incelemektir. Yukarıda tartışılan gelir karşılaştırması türlerinden diğer kişilere göre bireyin genel refah düzeyi ile bireyin geçmişteki refah düzeyi gözetilerek gelir ve mutluluk arasındaki ilişki Türkiye örneklemi üzerinde incelenmiştir.

\section{Araștırmanın Yöntemi}

\section{1. Örneklem}

$\mathrm{Bu}$ araştırmada, Türkiye İstatistik Kurumu (TUİK) tarafindan 2012 yılında yapılan Yaşam Memnuniyeti Araştırması'ndan elde edilen veri analiz edilmiştir. Yaşam Memnuniyeti Araştırması TUIKK tarafından 2003 yılından itibaren düzenli olarak her yıl yapılmaktadır. Genel olarak, Yaşam Memnuniyeti Araştırması'nın amacı Türkiye'deki bireylerin öznel mutluluk algılaması, sağlık, sosyal güvenlik, örgün eğitim, çalışma hayatı, gelir, kişisel güvenlik ve adalet hizmetleri, kişisel gelişim gibi temel yaşam alanlarındaki memnuniyetlerinin ölçülmesi ve bunların zaman içerisindeki değişiminin takip edilmesidir. Yaşam Memnuniyeti Araştırması, Türkiye'deki kent ve kır yerleşim alanlarında yaşayan 18 ve daha yukarı yaştaki hanehalkı fertlerini kapsamaktadır. 2012 yılında yapılan Yaşam Memnuniyeti Araştırması'nda iki aşamalı tabakalı küme örnekleme yöntemi kullanılmıştır. $\mathrm{Bu}$ yöntemde, ilk aşamada ortalama 100 haneden oluşan kümeler (bloklar) örneğe seçilmiş, ikinci aşamada ise örneğe seçilen kümelerden sistematik seçim yöntemi kullanılarak örnek adresler belirlenmiştir. Belirlenen bu örnek adreslerden kır ve kent yerleşim yerlerinden toplam 398 küme belirlenmiş, daha sonra bu örnek kümeden toplam 4196 hane örneğe 
seçilmiştir. Örneğe çıkan bu hanelerden 4069'u ile görüşme yapılarak, toplam 7956 birey araştırmanın örneklemini oluşturmuştur.

2012 Yaşam Memnuniyeti Araştırması'na katılan 7956 cevaplı birey arasında 5861 kişi $(\%$ 73,67) kentte, 2095 kişi $(\%$ 26,33) kırsal kesimdeki hanedendir. Cinsiyetlerine bakıldığında örneklemin 4447'si (\% 55,9) erkek, 3509'u ise (\% 44,1) kadındır. Örneklemin büyük çoğunluğu (6858 kişi; \% 86,2) lise ve aşağı derecede eğitim düzeyine sahiptir. Gelir düzeyi açısından bakıldığında, örneklemin büyük bir kısmı (6078 kişi; \% 76,4) 2060 TL ve altında, 1297 kişi (\% 16,3) 2061-3850 TL arasında ve 581 kişi ise (\% 7,3) 3851 TL ve yukarısında aylık toplam net gelire sahip olduğu görülmektedir. Yaş ortalaması ise 44,46'dır $(\mathrm{S} . \mathrm{S} .=16,30)$.

\subsection{Veri Toplama Aracı}

2012 Yaşam Memnuniyeti Araştırması, bireylerin iş ve yaşam hakkındaki genel sübjektif değerlendirmelerini kapsadığı gibi, çeşitli sosyo-ekonomik, demografik özellikler, sağlık, evlilik, eğitim, oturulan yer, gelir, ilişkiler ve kamu hizmetlerinden duyulan memnuniyet hakkında da bilgi sağlamaktadır. Bu çalışmanın amacı gelir ve mutluluk arasındaki ilişkide gelir karşılaştırmasının etkisini incelemek olduğu için sadece söz konusu değişkenlere ait ölçümler dikkate alınmıştır. Aşağıda görüldüğü üzere, 2012 Yaşam Memnuniyeti Araştırması'nda gelir düzeyi, mutluluk ve gelir karşılaştırmasına yönelik olarak bireylere tek maddeden oluşan genel bir ölçme sorusu yöneltilmiştir. Her ne kadar, tek maddelik ölçüm araçları konusunda araştırmacıların temkinli yaklaşımı olsa da, mutluluk ve gelir karşılaştırmasını tek maddede ölçen ölçüm araçlarının oldukça güvenilir sonuçlar verdiği görülmektedir (Judge \& Klinger, 2008; Firebaugh \& Schroeder, 2009).

\subsubsection{Mutluluk}

2012 Yaşam Memnuniyeti Araştırması'nda bireyler mutluluk düzeyleri hakkındaki değerlendirmelerini "Bir bütün olarak yaşamınızı düşündüğünüzde ne kadar mutlusunuz?" şeklindeki soruya 5'li Likert tarzında (1- çok mutsuz, 2- mutsuz, 3- orta, 4mutlu ve 5- çok mutlu) oluşturulan şıklardan birini işaretleyerek cevap vermişlerdir ${ }^{1}$.

12012 Yaşam Memnuniyeti Araştırması'nda bu soruya verilen cevaplar "1 - çok mutlu, 2 - mutlu, 3 - orta, 4 mutsuz, 5 - çok mutsuz" şeklinde kodlanmıştır. Bu çalışmada ele alınan diğer değişkenlerin yönüyle paralellik sağlanması açısından ters kodlama yapılmış ve analize bu şekilde sokulmuştur. 


\subsubsection{Gelir Düzeyi}

2012 Yaşam Memnuniyeti Araştırması'nda bireyler hanehalkı geliri hakkındaki değerlendirmelerini "Hanenin aylık toplam net geliri (maaş, ücret, kira, faiz, müteşebbis vb. gelirleri)" şeklindeki soruya 6'lı Likert tarzında (1 (0-849 TL), 2 (850-1180TL), 3 (1181$1550 \mathrm{TL}), 4$ (1551-2060 TL), 5 (2061-3850 TL) ve $6(3851+\mathrm{TL}))$ oluşturulan şıklardan birini tercih ederek cevap vermişlerdir.

\subsubsection{Gelir Karşılaştırması}

2012 Yaşam Memnuniyeti Araştırması'nda bireyler gelir karşılaştırmalarını iki ayrı soruya cevap vererek değerlendirmişlerdir. Birinci soru algılanan refah düzeyi ile ilgilidir ve "Türkiye'de yaşayan insanların refah düzeyini " 0 ” basamağ en düşük, "10" basamağı en yüksek düzey olarak düşündüğünüzde kendinizi hangi düzeyde görüyorsunuz?” şeklindedir. Bu soruya bireyler 1'den 10'a kadar değişen skalada uygun bir rakamı işaretleyerek cevap vermişlerdir. İkinci soru ise bireyin mevcut durumunu geçmiş durumu ile karşılaştırmasına yöneliktir ve " 5 yıl öncesi ile karşılaştırdığınızda bugünkü durumunuzu (maddi veya manevi) nasıl görüyorsunuz?” şeklindedir. Bu soruya bireyler (1- gelişmiş, 2aynı seviyede kalmış ve 3- gerilemiş) şeklinde oluşturulan şıklardan birini işaretleyerek cevap vermişlerdir.

\section{3. İşlem}

Analize tabi tutulan değişkenler (mutluluk, gelir, gelir karşılaştırması) her ne kadar sıralı (ordinal) türde ölçülmüş olsa da, birçok araştırmacı bu türde ölçülmüş veriyi metrik veri olarak ele almaktadır. Beş ve daha fazla sıralı kategoride ölçümlenmiş veriyi metrik veri olarak ele almanın bir problem yaratmadığı belirtilmiştir (Johnson \& Creech, 1983; Zumbo \& Zimmerman, 1993). Bu nedenle, araştırmanın amacı kapsamında, bireylerin mutlulukları üzerinde gelirin ve gelir karşılaştırmasının tek tek etkisi ve birlikte etkisinin (interaction) belirlenmesi amacıyla hiyerarşik regresyon analizi kullanılmıştır. Hiyerarşik regresyon analizinin ilk aşamasında gelir ve gelir karşılaştırması analize sokulmuş, ikinci aşamada ise gelir ve gelir karşılaştırmasının çarpımsal terimi (interaction term) analize sokulmuştur (Cohen \& Cohen, 1983). Bütün analizler için .05 anlamlılık düzeyi esas alınmıştır.

\subsection{Bulgular}

Araştırmada öncelikle, mutluluk ile diğer değişkenler arasındaki ilişki düzeyinin tespiti yapılmıştır. Daha sonra, mutluluk üzerinde gelirin ve gelir karşılaştırmasının tek tek 
etkisi ile ortak etkisi analiz edilmiştir. Tablo 1'de araştırma değişkenleri ve diğer demografik değişkenler arasındaki ilişkileri gösterir korelâsyon analizi sonuçları yer almaktadır.

Tablo: 1

Değişkenler Arasındaki Korelâsyon Analizi Sonuçları

\begin{tabular}{|c|c|c|c|c|c|c|c|c|}
\hline Değişkenler & Ort. & S.S. & 1 & 2 & 3 & 4 & 5 & 6 \\
\hline $\begin{array}{ll}1 & \text { Yaş } \\
\end{array}$ & 44.46 & 16.30 & - & & & & & \\
\hline 2 Cinsiyet & 1.56 & 0.49 & -0.017 & - & & & & \\
\hline $\begin{array}{l}\text { Aylık Hanehalkı } \\
\text { Geliri }\end{array}$ & 3.07 & 1.60 & $-0.123 * *$ & $-0.050 * *$ & - & & & \\
\hline $\begin{array}{l}\text { Algilanan Refah } \\
\text { Düzeyi }\end{array}$ & 5.26 & 1.79 & $-0.090 * *$ & $-0.024 * *$ & $0.358^{* *}$ & - & & \\
\hline $5 \begin{array}{l}\text { Geçmiş ile } \\
\text { karşılaștırma }\end{array}$ & 2.13 & 0.79 & $-0.168 * *$ & $0.027 *$ & $0.180^{* *}$ & $0.286^{* *}$ & - & \\
\hline 6 Mutluluk & 3.57 & 0.82 & $-0.056 * *$ & 0.017 & $0.172 * *$ & $0.307 * *$ & $0.255^{* *}$ & - \\
\hline
\end{tabular}

$* * p<0.01 * p<0.05$. Cinsiyet değişkeni erkek (1) kadın (2) şeklinde kodlanmıştır.

Tablo 1'deki sonuçlara bakıldığında yaşın aylık hanehalkı geliri ile $(r=-0.123$, $p<0.01)$, algılanan refah düzeyi ile $(r=-0.090, p<0.01)$, geçmiş durum karşılaştırması ile $(r=-0.168, p<0.01)$ ve mutluluk ile $(r=-0.056, p<0.01)$ negatif yönde ilişkili olduğu bulunmuştur. Bununla birlikte mutluluk ile aylık hanehalk1 geliri $(r=0.172, p<0.01)$, algılanan refah düzeyi $(r=0.307, p<0.01)$ ve geçmiş durum karşılaştırması $(r=0.255, p<$ 0.01) arasında pozitif yönlü ilişkiler olduğu görülmüştür. Bu ilişkiler, mutluluk ve söz konusu değişkenlerin birlikte ve aynı yönlü değişimine işaret etmektedir.

Çalışmanın ana amacı olan "mutluluk üzerinde, gelirin ve gelir karşılaştırmasının tek tek etkisi ile birlikte etkisini”" test etmek için hiyerarşik regresyon analizi yapılmıştır. Analizde mutluluk bağımlı değişken, gelir ve gelir karşılaştırması ise bağımsız değişkenler olarak işleme alınmıştır. Hiyerarşik regresyon analizinin ilk aşamasında gelir ve gelir karşılaştırması analize sokulmuş, ikinci aşamada ise gelir ve gelir karşılaştırmasının çarpımsal terimi (interaction term) analize sokulmuştur. İkinci aşamada regresyon modeline sokulan gelir ve gelir karşılaştırmasının çarpımsal teriminin anlamlı olması ve $\mathrm{R}^{2}$ değerinde anlamlı bir fark çıkarması, bu iki değişkenin mutluluk üzerinde etkileşim (interaction) etkisinin olacağını göstermektedir (Aiken \& West, 1991; Frazier vd., 2004; Gürbüz \& Şahin, 2015).

Tablo 2'de mutluluk üzerinde etkileri olan değişkenlerin hiyerarşik regresyon analizi sonuçları yer almaktadır. Birinci aşamada analize sokulan aylık hanehalkı geliri ve geçmiş ile karşılaştırmanın $R^{2}$ değerini $0.081(p<0.01)$ oranında artırdığ 1 görülmüştür. Bununla birlikte, mutluluk üzerinde aylık hanehalkı gelirinin $(B=0.074, p<0.01)$ pozitif; geçmiş ile karşılaştırmada "gelişmiş" cevabı verenlerin (GK1) $(B=-0.361, p<0.01)$ negatif 
yönde; geçmiş ile karşılaştırmada "gelişmemiş" cevabı verenlerin (GK2) $(B=0.149, p$ < 0.01 ) pozitif yönde etkilerinin olduğu görülmektedir. Aylık hanehalkı gelirinin ve geçmiş ile karşılaştırmanın çarpımsal sonucunun ikinci aşamada analize girilmesiyle birlikte $R^{2}$ değerinde bir artış sağlamadığı görülmüştür. Başka bir ifadeyle, bireylerin mutluluk düzeyleri üzerinde, aylık hanehalkı gelirinin ve geçmiş ile karşılaştırmanın çarpımsal sonuçlarının anlamlı bir etkisi yoktur. İlerleyen kısımda, gelir ile refah düzeyi algılamasının mutluluk üzerinde tek tek ve birlikte etkisine yönelik analiz sonuçları yer almaktadır.

Tablo: 2

Mutluluk Üzerine Etkileri Olan Değişkenlere Ait Hiyerarşik Regresyon Analizi Sonuçları

\begin{tabular}{|c|c|c|c|c|}
\hline \multirow{2}{*}{ Aşamalar ve Değiş̧kenler } & \multicolumn{2}{|c|}{ Birinci Aşama } & \multicolumn{2}{|c|}{ İkinci Aşama } \\
\hline & $\boldsymbol{B}$ & $T$ & $\boldsymbol{B}$ & $T$ \\
\hline \multicolumn{5}{|l|}{ Temel Etkiler } \\
\hline Aylık Hanehalkı Geliri (HHG) & 0.074 & $4.242 * *$ & 0.061 & $6.378 * *$ \\
\hline Geçmiş ile Karşılaştırma (GK1) & -0.361 & $-7.894 * *$ & -0.382 & $-8.028 * *$ \\
\hline Geçmiş ile Karşılaştırma (GK2) & 0.149 & $3.222 * *$ & 0.157 & $3.328 * *$ \\
\hline \multicolumn{5}{|l|}{ Çarpımsal Etki } \\
\hline HHG x GK1 & & & 0.018 & 1.243 \\
\hline HHG x GK2 & & & 0.001 & 0.137 \\
\hline $\begin{array}{l}F \\
\Delta F\end{array}$ & \multicolumn{2}{|c|}{$346.130 * * *$} & \multicolumn{2}{|c|}{$231.668^{* * * *}$} \\
\hline & \multirow{2}{*}{\multicolumn{2}{|c|}{$0.081 \stackrel{-}{(0.081)}$}} & \multicolumn{2}{|c|}{2.603} \\
\hline \multirow{2}{*}{$\begin{array}{l}R^{2}\left(\text { Düz. } R^{2}\right) \\
\Delta R^{2}\end{array}$} & & & \multicolumn{2}{|c|}{$0.081(0.081)$} \\
\hline & \multicolumn{2}{|c|}{$\begin{array}{c}0.081(0.081) \\
-\end{array}$} & & - \\
\hline
\end{tabular}

Tablo 3'de mutluluk üzerinde etkileri olan değişkenlerin hiyerarşik regresyon analizi sonuçları yer almaktadır. Birinci aşamada analize sokulan aylık hanehalkı geliri ve refah düzeyinin $R^{2}$ değerini $0.098(p<0.01)$ oranında artırdığ görülmüştür. Bununla birlikte, mutluluk üzerinde aylık hanehalkı gelirinin $(B=0.069, p<0.01)$ ve refah düzeyinin $(B=0.165, p<.01)$ pozitif yönde etkilerinin olduğu görülmektedir. Bu sonuçlar, aylık hanehalkı gelirinin ve algılanan refah düzeyinin artması durumunda bireylerin mutluluk düzeylerinin yükseldiğini göstermektedir. Aylık hanehalkı gelirinin ve refah düzeyinin çarpımsal sonucunun ikinci aşamada analize girilmesiyle birlikte $R^{2}$ değerinde 0.001 ( $p<$ 0.05 ) oranında bir artış sağladığı görülmüştür. Başka bir ifadeyle, bireylerin mutluluk düzeyleri üzerinde, aylık hanehalkı gelirinin ve algılanan refah düzeyin birlikte etkisi her birinin tek tek etkisinden $\% 0.1$ oranında daha fazladır. 
Tablo: 3

Mutluluk Üzerine Etkileri Olan Değişkenlere Ait Hiyerarşik Regresyon Analizi Sonuçları

\begin{tabular}{|c|c|c|c|c|}
\hline \multirow{2}{*}{ Aşamalar ve Değişkenler } & \multicolumn{2}{|c|}{ Birinci Aşama } & \multicolumn{2}{|c|}{ İkinci Aşama } \\
\hline & & $T$ & & $T$ \\
\hline \multicolumn{5}{|l|}{ Temel Etkiler } \\
\hline Aylık Hanehalkı Geliri (HHG) & 0.069 & $5.979 * *$ & 0.071 & $4.130 * *$ \\
\hline Refah Düzeyi (RD) & 0.165 & $15.651 * *$ & 0.149 & $14.560 * *$ \\
\hline \multicolumn{5}{|l|}{ Çarpımsal Etki } \\
\hline HHG x RD & & & -0.098 & $-2.235^{*}$ \\
\hline$F$ & \multicolumn{2}{|c|}{$429.462 * * *$} & \multicolumn{2}{|c|}{$288.119 * * *$} \\
\hline$\Delta F$ & \multicolumn{2}{|c|}{-} & \multicolumn{2}{|c|}{$4.996^{* *}$} \\
\hline$R^{2}$ (Düz. $\left.R^{2}\right)$ & \multicolumn{2}{|c|}{$0.098(0.098)$} & \multicolumn{2}{|c|}{$0.099(0.098)$} \\
\hline$\Delta R^{2}$ & \multicolumn{2}{|c|}{-} & \multicolumn{2}{|c|}{0.001} \\
\hline
\end{tabular}

Aylık hanehalkı gelirinin ve algılanan refah düzeyinin çarpımsal sonucunun anlamlı olması, bu iki değişkenin mutluluk üzerinde etkileşiminin $(B=-0.098, p<0.05)$ var olduğunu göstermektedir. Aiken ve West'in (1991: 157) önerileri doğrultusunda, aylık hanehalkı gelirinin ve algılanan refah düzeyinin çarpımsal sonucunun etki büyüklüğü (effect size) ise $\mathrm{f}^{2}=0.0011$ olarak hesaplanmıştır. Bu etki büyüklüğü, değeri itibariyle küçük olsa da, deneysel olmayan çalışmalardan elde edilen sonuçlar arasında gerçekçi ve kabul edilebilir düzeydedir (Aguinis vd., 2005). Aylık hanehalkı gelirinin ve algılanan refah düzeyinin birlikte etkisinin biçimini ve yönünü belirlemek için; düşük ve yüksek düzeydeki (ortalama değerinden +1 ve -1 standart sapmadaki) algılanan refah düzeyi durumunda aylık hanehalk1 gelirinin mutluluk üzerindeki etkisi grafiksel olarak Şekil 1'de gösterilmiş̧ir (Stone \& Hollenbeck, 1989; Aiken \& West, 1991). 
Şekil: 1

Düşük ve Yüksek Refah Düzeyinde Gelirin Mutluluk Üzerinde Etkisi

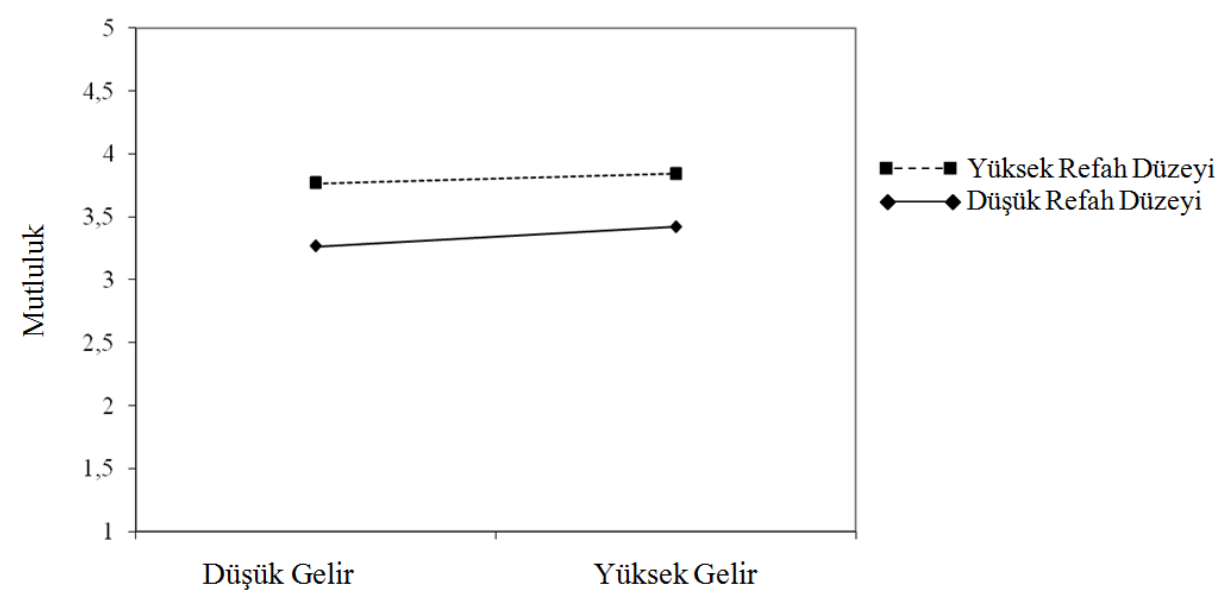

Şekil 1, mutluluk üzerinde aylık hane gelirinin ve refah düzeyi algılamasının birlikte etkisinin var olduğunu göstermektedir. Düşük ve yüksek düzeyde aylık hane geliri olan bireylerin, düşük ve yüksek düzeydeki (ortalama değerinden +1 ve -1 standart sapmadaki) refah düzeyi etkileşiminin olduğu durumlarda mutluluk düzeyleriyle olan ilişkisini gösteren Şekil: 1'deki eğimlerin, 0 (sıfır) değerinden anlamlı düzeyde farklılaşıp farklılaşmadığı eğim testi (slope test) ile analiz edilmiştir (Aiken \& West, 1991). Bu test, gelir ile mutluluk arasındaki ilişkinin refah düzeyi algılamasına bağlı olup olmadığını ortaya koymaktadır. Düşük refah düzeyi algılayan bireyler için gelir ile mutluluk arasındaki ilişki anlamlı ve pozitif yönlüdür $(B=0.048, p<0.01)$. Yüksek refah düzeyi algılayan bireyler için ise bu ilişki anlamlı ve pozitif yönlü olmakla birlikte daha zayıftır $(B=0.024, p<0.01)$. $\mathrm{Bu}$ sonuçlara göre, bireyler başkalarına göre kendi refah düzeyi algılamasında yükseldikçe, gelirin mutluluk üzerindeki etkisi zayıflamaktadır.

\section{Sonuç ve Tartışma}

$\mathrm{Bu}$ çalışmanın amacı, gelir ile mutluluk arasındaki ilişkide bireylerin gelir durumlarını karşılaştırmalarının etkisini incelemektir. Araştırma kapsamında gelir karşılaştırması türlerinden diğer kişilere göre bireyin genel refah düzeyi ile bireyin geçmişteki refah düzeyi dikkate alınmıştır. 
Elde edilen bulgular, aylık hanehalk1 gelirinin $(B=0.074, p<0.01)$ mutluluk üzerinde pozitif yönlü bir etkisinin olduğunu göstermiştir. Ayrıca, bireylerin 5 yıl öncesine göre mevcut durumlarını "gelişmemiş" şeklinde karşılaştırmaları mutluluk üzerinde pozitif yönlü bir etki ortaya çıkarmıştır. Diğer taraftan, geçmiş ile karşılaştırmada "gelişmiş” cevabı verenlerin mutluluk üzerinde negatif yönlü bir etkisinin olduğu bulunmuştur. Ortaya çıkan bu sonuç, mevcut durumları geçmişten daha iyi olan bireylerin, mutluluk düzeylerinde bir azalmayı ifade etmektedir. Bu durum, bireylerin gelişen durumlarıyla birlikte beklentilerinin de aynı yönde arttığı ve artan beklentilerin mutluluk düzeylerini azalttığı şeklinde yorumlanabilir. Bunun yanında, mevcut durumları gelişmesine rağmen bireyler amaçlarına ulaşamamış olabilirler. Böyle bir durum da gelişim gösteren bireylerin mutlu olamamaları sonucunu doğurabilir. Diğer taraftan, aylık hanehalkı gelirinin ve geçmiş ile karşılaştırmanın çarpımsal teriminin analizin ikinci aşamasında analize dâhil edilmesiyle birlikte, bu iki değişkenin mutluluk üzerinde çarpımsal sonuçlarının anlamlı bir etkisinin olmadığı ortaya çıkmıştır. Bu sonuca göre, mevcut durumu geçmiş ile karşılaştırmanın, gelir ile mutluluk arasındaki ilişkide bir rolünün olmadığı söylenebilir. $\mathrm{Bu}$ anlamda, gelirin mutluluk üzerindeki etki seviyesinin bireyden bireye farklılaşması bu sonuca neden olmuş olabilir. Ayrıca, bireysel mutluluğa etki eden gelir dışındaki faktörler dikkate alındığında, mutlu bir yaşama dair düşüncelerin göreceli bir özelliğe sahip olduğu gerçeği göz ardı edilmemelidir. Bunun yanında, belirli bir gelir düzeyinin üzerindeki artışlar, mutluluğu yükseltici bir faktör olarak değerlendirilmeyebilir. Son olarak, bireylerin mevcut ekonomik koşullara hızlı bir şekilde adapte olması da genel mutluluk düzeylerinde bir değişime yol açmayabilir.

Araştırma sonucunda ortaya çıkan diğer önemli bulgu ise, mutluluk üzerinde aylık hanehalkı gelirinin $(B=0.069, p<0.01)$ ve diğer kişilere göre bireyin genel refah düzeyinin pozitif yönde etkisinin olduğudur. Buna göre, aylık hanehalkı geliri ve algılanan refah düzeyi arttıkça bireylerin mutluluk düzeyleri de yükselmektedir. Ayrıca, bu iki değişkenin mutluluk üzerindeki çarpımsal etkisinin anlamlı olduğu görülmüştür. Bu doğrultuda gerçekleştirilen eğim testi sonucuna göre, bireylerin refah düzeyi algılaması arttıkça, aylık hanehalkı gelirinin mutluluk üzerindeki etkisinin azaldığı ortaya çıkmıştır. Buna göre, bireylerin referans grupla yaptıkları gelir kıyaslamasında kendi gelirlerinin yüksek olduğuna kanaat getirmeleri sonucunda mutluluk düzeylerinde bir artış yaşanmamaktadır. Bu bulgu her ne kadar, Diener vd. (2013) tarafından yapılan çalışma sonuçlarıyla benzerlik gösterse de, alan yazında gerçekleştirilen bazı çalışma sonuçlarıyla farklılık arz etmektedir (Ferrer-i-Carbonell, 2005; Firebaugh \& Schroeder, 2009; McBride, 2010; Dumludag, 2013; Caner, 2014). Bu durumun birkaç nedeni olabilir: Birincisi, tatminsiz bireyler yaşam şartları olağanüstü olsa bile mutlulukları artmayabilir, hatta mutsuz olabilirler. İkinci olarak, her yeni gelişimin yeni bir beklentiye neden olmasından dolayı, bireylerin sürekli mutluluğu yakalaması pek mümkün görünmemektedir. Son olarak, bireylerin gelecekte daha iyi koşullar altında yaşayacaklarına dair inançları, bugünü göz ardı etmelerine neden olabilmekte ve böylece amaçlanan mutluluk ile gerçekleşen mutluluk arasındaki mesafe açılabilmektedir. 
$\mathrm{Bu}$ araştırmanın iki temel kısıtı bulunmaktadır. İlk kısıt, veri toplama yöntemiyle ilgilidir. Anket yöntemi kullanılarak yapılan bu araştırmada verilerin tek bir kaynaktan (bireyin kendisi) toplanması yanlılığa neden olabilmektedir. Bu durum, analiz sonucunda ortaya çıkan doğrusal ilişkilerin büyüklüğünü artırabilmektedir (Podsakoff vd., 2003). Araştırmanın bir diğer kısıtı ise bu araştırmanın aslında kesitsel bir araştırma olmasından kaynaklanmaktadır. Kesitsel araştırma, belirli bir zaman diliminde yapılan bir alan araştırması olduğu için değişkenler arasındaki nedensel ilişkilerden bir sonuç çıkarmak her zaman mümkün değildir. Bu nedenle, ileride yapılacak çalışmalarda, belirli bir zaman diliminde verilerin toplanması yerine, boylamsal bir araştırma tasarımı ile bu kısıt engellenebilir ve değişkenler arasındaki nedensel ilişkiler daha güvenilir hale gelebilir.

Sonuç olarak, aylık hanehalkı geliri ile mutluluk arasındaki ilişkide mevcut durumu geçmiş ile kıyaslamanın etkili olmadığı, ancak refah düzeyi algılamasının etkili olduğu görülmüştür. Bu bulgular, yüksek refah düzeyi algılaması durumlarında bile bireylerin mutlu olamadıklarını ortaya koyması açısından önem arz etmektedir.

\section{Kaynakça}

Aiken, L.S. \& S.G. West (1991), Multiple Regression: Testing and Interpreting Interactions, Newbury Park, CA, Sage.

Aguinis, H. \& J.C. Beaty \& R.J. Boik \& C.A. Pierce (2005), "Effect Size and Power in Assessing Moderating Effects of Categorical Variables Using Multiple Regression: A 30-Year Review", Journal of Applied Psychology, 90, 94-107.

Arthaud-Day, M.L. \& J.P. Near (2005), "The Wealth of Nations and the Happiness of Nations: Why “Accounting” Matters", Social Indicators Research, 74, 511-548.

Ball, R. \& K. Chernova (2008), “Absolute Income, Relative Income and Happiness”, Social Indicators Research, 88, 497-529.

Boyce, C.J. \& G.D.A. Brown \& S.C. Moore (2010), "Money and Happiness: Rank of Income, Not Income Affects Life Satisfaction”, Psychological Science, 21(4), 471-475.

Caner, A. (2014), "Happiness, Comparison Effects and Expectations in Turkey", Journal of Happiness Studies, Research paper, DOI 10.1007/s10902-014-9562-z.

Caporale, G.M. \& Y. Georgellis \& N. Tsitsianis \& Y.P. Yin (2009), "Income and Happiness Across Europe: Do Reference Values Matter?", Journal of Economic Psychology, 30, 42-51.

Clark, A.E. \& A.J. Oswald (1996), "Satisfaction and Comparison Income", Journal of Public Economics, 61, 359-381.

Clark, A.E. \& P. Frijters \& M.A. Shields (2008), "Relative Income, Happiness and Utility: An Explanation for the Easterlin Paradox and Other Puzzles", Journal of Economic Literature, 46(1), 95-144.

Cohen, J. \& P. Cohen (1983), Applied Multiple Regression/Correlation Analysis for the Behavioral Sciences, 2nd ed., Hillsdale, NJ: Erlbaum. 
Cummins, R.A. (2000), "Personal Income and Subjective Well-Being: A Review”, Journal of Happiness Studies, 1, 133-158.

Diener, E. \& E. Sandvik \& L. Seidlitz \& M. Diener (1993), "The Relationship Between Income and Subjective Well-Being: Relative or Absolute?", Social Indicators Research, 28, 195-223.

Diener, E. \& L. Tay \& S. Oishi (2013), "Rising Income and the Subjective Well-Being of Nations", Journal of Personality and Social Psychology, 104(2), 267-276.

Diener, E. \& M. Diener (1995), "Cross-Cultural Correlates of Life Satisfaction and Self-Esteem", Journal of Personality and Social Psychology, 68(4), 653-663.

Diener, E. \& M. Diener \& C.L. Diener (1995), "Factors Predicting the Subjective Well-Being of Nations", Journal of Personality and Social Psychology, 69, 851-864.

Diener, E. \& M.E.P. Seligman (2004), "Beyond Money. Toward an Economy of Well-Being”, Psychological Science in the Public Interest, 5(1), 1-31.

Diener, E. \& R. Biswas-Diener (2002), “Will Money Increase Subjective Well-Being?”, Social Indicators Research, 57, 119-169.

Diener, E. \& S. Oishi (2000), "Money and Happiness: Income and Subjective Well-Being across Nations", in: E. Diener \& E.M. Suh (Eds.), Culture and Subjective Well-Being, Cambridge, MA: MIT Press, 185-218.

Dolan, P. \& T. Peasgood \& M. White (2008), "Do We Really Know What Makes Us Happy? A Review of the Economic Literature on the Factors Associated with Subjective WellBeing", Journal of Economic Psychology, 29, 94-122.

Dumludag, D. (2013), “Life Satisfaction and Income Comparison Effects in Turkey”, Social Indicators Research, 114, 1199-1210.

Duncan, O.D. (1975), “Does Money Buy Satisfaction”, Social Indicators Research, 2, 267-274.

Easterlin, R.A. (1995), "Will Raising the Incomes of All Increase the Happiness of All”, Journal of Economic Behavior and Organization, 27, 35-47.

Easterlin, R.A. (2001), "Income and Happiness: Towards a Unified Theory”, The Economic Journal, 111(473), 465-484.

Erdogan, B. \& T.N. Bauer \& D.M. Truxillo \& L.R. Mansfield (2012), "Whistle While You Work: A Review of the Life Satisfaction Literature”, Journal of Management, 38(4), 1038-1083.

Ferrer-i-Carbonell, A. (2005), "Income and Well-Being: An Empirical Analysis of the Comparison Income Effect”, Journal of Public Economics, 89, 997-1019.

Firebaugh, G. \& M.B. Schroeder (2009), "Does Your Neighbor's Income Affect Your Happiness?”, American Journal of Sociology, 115(3), 805-831.

Frazier, P.A. \& P.A. Tix \& K.E. Barron (2004), “Testing Moderator and Mediator Effects in Counseling Psychology Research”, Journal of Counseling Psychology, 51(1), 115-134.

Frey, B.S. \& A. Stutzer (2002), "What Can Economists Learn from Happiness Research", Journal of Economic Literature, 40, 402-435.

Gürbüz, S. \& F. Şahin (2015), Sosyal Bilimlerde Araştırma Yöntemleri: Felsefe-Yöntem-Analiz, (2.Baskı), Ankara, Seçkin Yayıncılık. 
Hagerty, M.R. \& R. Veenhoven (2003), "Wealth and Happiness Revisited-Growing National Income Does Go with Greater Happiness", Social Indicators Research, 64, 1-27.

Headey, B. \& R. Muffels \& M. Wooden (2008), "Money Does not Buy Happiness: Or It Does? A Reassessment Based on the Combined Effects of Wealth, Income and Consumption", Social Indicators Research, 87, 65-82.

Johnson, D.R. \& J.C. Creech (1983), “Ordinal Measures in Multiple Indicator Models: A Simulation Study of Categorization Error", American Sociological Review, 48, 398-407.

Judge, T.A. \& R. Klinger (2008), "Job satisfaction: Subjective Well-Being at Work”, in: M. Eid \& R.J. Larsen (Eds.), The science of subjective well-being, New York: The Guilford Press.

McBride, M. (2001), "Relative-Income Effects on Subjective Well-Being in the Cross-Section", Journal of Economic Behavior \& Organization, 45, 251-278.

McBride, M. (2010), "Money, Happiness and Aspirations: An Experimental Study", Journal of Economic Behavior \& Organization, 74, 262-276.

Near, J.P. \& R.W. Rice \& R.G. Hunt (1978), "Work and Extra-Work Correlates of Life and Job Satisfaction", Academy of Management Journal, 21(2), 248-264.

Oishi, S. \& S. Kesebir \& E. Diener (2011), "Income Inequality and Happiness", Psychological Science, 22(9), 1095-1100.

Oshio, T. \& K. Nozaki \& M. Kobayashi (2011), "Relative Income and Happiness in Asia: Evidence from Nationwide Surveys in China, Japan and Korea", Social Indicators Research, 104, 351-367.

Podsakoff, P.M. \& S.B. Mackenzie \& J.Y. Lee \& N.P. Podsakoff (2003), “Common Method Biases in Behavioral Research: A Critical Review of the Literature and Recommended Remedies", Journal of Applied Psychology, 88, 879-903.

Rojas, M. (2007), "Heterogeneity in the Relationship between Income and Happiness: A Conceptual Referent Theory Explanation", Journal of Economic Psychology, 28, 1-14.

Senik, C. (2005), "Income Distribution and Well-Being: What Can We Learn from Subjective Data", Journal of Economic Surveys, 19(1), 43-63.

Stone, E.F. \& J.R. Hollenbeck (1989), "Clarifying Some Controversial Issues Surrounding Statistical Procedures for Detecting Moderator Variables: Empirical Evidence and Related Evidence", Journal of Applied Psychology, 74, 3-10.

Stutzer, A. (2004), "The Role of Income Aspirations in Individual Happiness", Journal of Economic Behavior \& Organization, 54, 89-109.

Van Praag, B.M.S. \& B.E. Baarsma (2005), "Using Happiness Surveys to Value Intangibles: The Case of Airport Noise", The Economic Journal, 115(500), 224-246.

Veenhoven, R. (1991), “Is Happiness Relative?”, Social Indicators Research, 24, 1-34.

Zumbo, B.D. \& D.W. Zimmerman (1993), "Is the Selection of Statistical Methods Governed by Level of Measurement?", Canadian Psychology, 34, 390-400. 
Köksal, O. \& F. Şahin (2015), "Gelir ve Mutluluk: Gelir Karșılaștırmasının Etkisi”, Sosyoekonomi, Vol. 23(26), 45-59. 